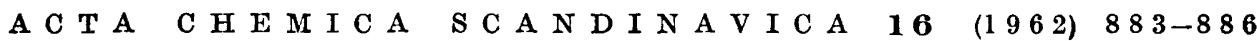

\title{
The Hemiacetal of Chloral with Testosterone and Derivatives thereof
}

\author{
POUL BORREVANG
}

Leo Pharmaceutical Products, Copenhagen, Denmark

\begin{abstract}
Treatment of testosterone with chloral yields the 1-hydroxy-2,2,2trichloroethyl ether of testosterone. With acid anhydrides or acyl chlorides the corresponding esters are obtained. The hydroxyether reacts with $\mathrm{PCI}_{5}$ to the 1,2,2,2-tetrachloroethyl ether, which together with $\mathrm{KOH}$ in ethanol leads to the 1,2,2-trichlorovinyl ether.
\end{abstract}

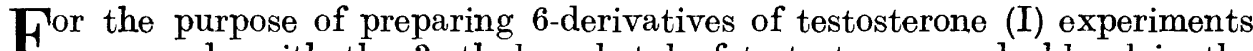
Were made with the 3-ethylene ketal of testosterone and chloral in the presence of peroxides to obtain a free-radical reaction. It was possible to isolate a substance of the desired composition $\mathrm{C}_{23} \mathrm{H}_{33} \mathrm{Cl}_{3} \mathrm{O}_{4}$. The ultraviolet spectrum showed no maxima, but hydrolysis in aqueous acetone with sulphuric acid transformed the substance into testosterone.

The formation of testosterone by hydrolysis indicated that no reaction between the $\Delta^{5}$-double bond and chloral had taken place. According to the analysis it seemed possible that the free OH-group in the 17-position had reacted with chloral and yielded a hemiacetal. Therefore testosterone was treated with chloral at room temperature without catalysts. This yielded a compound with an elementary analysis in agreement with the hemiacetal of chloral with testosterone (II). This substance, 17-(1-hydroxy-2,2,2-trichloroethoxy)androst-4-ene-3-one, showed in the infrared spectrum (in $\mathrm{KBr}$ ) the normal bands for a $\Delta^{4}$-3-keto group, a band for a hydroxyl-group, and a very strong band at $1117 \mathrm{~cm}^{-1}$, which indicated an ether-group. Compared to the infrared spectrum of testosterone the new strong bands at 797 and $832 \mathrm{~cm}^{-1}$ must be due to the $\mathrm{CCl}_{3}$-group.

By reaction of II with acetic anhydride in pyridine the corresponding acetate (IIIb) was formed. In the infrared spectrum of testosterone acetate the ester-carbonyl group shows a band at $1735 \mathrm{~cm}^{-1}$, in the acetate of the hemiacetal of chloral with testosterone this band was shifted to $1765 \mathrm{~cm}^{-1}$. The ether band, from the hemiacetal, was shifted to $1142 \mathrm{~cm}^{-1}$, but the bands for the $\mathrm{CCl}_{3}$-group were identical. A number of esters are listed in Table 1 . 


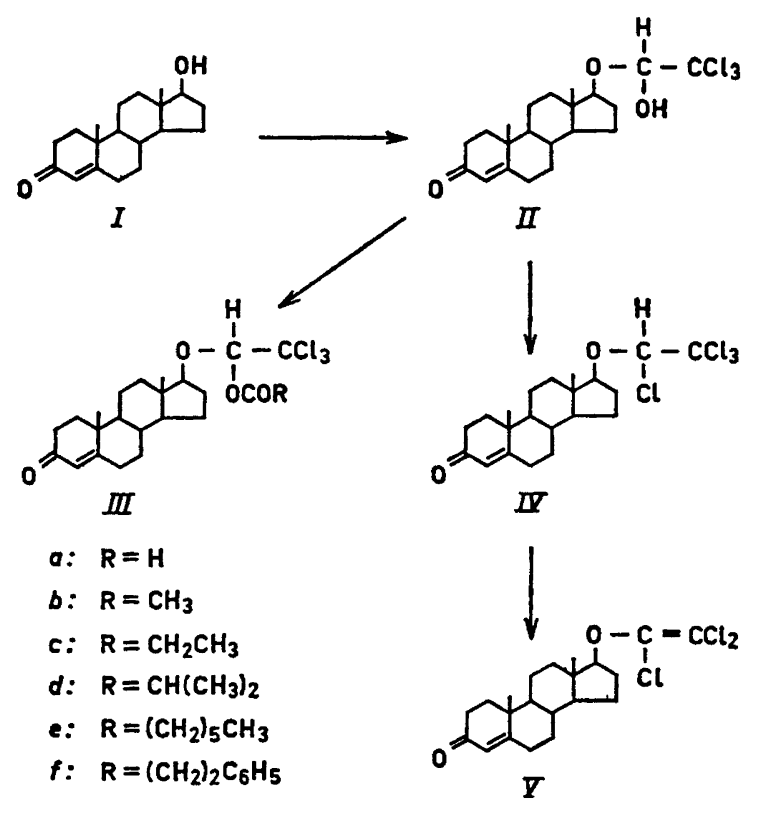

Treatment of II with $\mathrm{PCl}_{5}$ in chloroform yielded 17-(1,2,2,2-tetrachloroethoxy)-androst-4-ene-3-one (IV) and reflux of IV with $\mathrm{KOH}$ in aqueous ethanol yielded 17-(1,2,2-trichloroethenoxy)-androst-4-ene-3-one (V). The two compounds (IV and V) showed in the infrared spectrum normal bands for a $\Delta^{\mathbf{4}}$-3keto group, and no absorption for a $\mathrm{OH}$-group. The ether band was shifted to $1150 \mathrm{~cm}^{-1}$ for the tetrachloro ether and to $1165 \mathrm{~cm}^{-1}$ for the trichlorovinyl ether. The above-mentioned bands for the $\mathrm{CCl}_{3}$-group were weak in the tetrachloro ether, but the spectrum showed a new strong band for a C-Cl-group at $700 \mathrm{~cm}^{-1}$ whereas in the trichlorovinyl ether the $\mathrm{C}-\mathrm{Cl}$ frequency is as high as $805 \mathrm{~cm}^{-1}$ with a very strong absorption.

Biological properties. Gaunt et al. ${ }^{1}$ have established that the androgenic activity is greatly reduced by transforming the 17- $\mathrm{OH}$ group in testosterone to a methoxy group. The activity of the new ether (II) is in the rat test three to four times that of testosterone propionate whereas the activity of the acetate (IIIb) is only half of that of testosterone propionate, but the acetate shows a markedly protracted action. In aqueous suspension its activity as regards intensity and duration is higher than that of testosterone isobutyrate *. The compounds IV and V showed no androgenic activity.

\section{EXPERIMENTAL}

All melting points are uncorrected.

17-(1-Hydroxy-2,2,2-trichloroethoxy)-androst-4-ene-3-one (II). Testosterone (2.9 g) was added to a solution of chloral $(1.7 \mathrm{~g})$ in anhydrous benzene $(10 \mathrm{ml})$. By shaking the

* These experiments were carried out in the biological department of Leo Pharmaceutical Products.

Acta Chem. Scand. 16 (1962) No. 4 


\begin{tabular}{|c|c|c|c|c|c|c|c|}
\hline \multirow{2}{*}{$\begin{array}{l}\partial^{\circ} \\
\bar{\nu}\end{array}$} & $\vec{g}$ & $\begin{array}{l}\text { 今. } \\
\text { ్ํ }\end{array}$ & 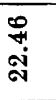 & ị & ڤ̊ & 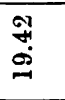 & $\begin{array}{l}5 \\
0 \\
\infty\end{array}$ \\
\hline & 迥 & 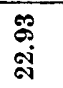 & 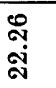 & 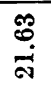 & 芯 & 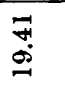 & $\begin{array}{l}\infty \\
\infty \\
\infty \\
\sim\end{array}$ \\
\hline \multirow{2}{*}{$\begin{array}{l}\circ \\
\text { 壮 }\end{array}$} & 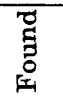 & $\overrightarrow{0 ̈}$ & :̈ & $\stackrel{\vec{t}}{0}$ & ণั & : & $\begin{array}{l}\mathscr{O} \\
\stackrel{0}{0}\end{array}$ \\
\hline & లే & 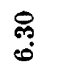 & 苟 & $\stackrel{0}{0}$ & $\underset{\phi}{\phi}$ & 菅 & to \\
\hline \multirow{2}{*}{$\begin{array}{l}0 \\
0\end{array}$} & $\begin{array}{l}\vec{Z} \\
\overrightarrow{0} \\
F\end{array}$ & $\begin{array}{l}\infty \\
\stackrel{0}{0} \\
0 \\
10\end{array}$ & $\begin{array}{l}8 \\
\stackrel{8}{8} \\
\stackrel{1}{10}\end{array}$ & $\begin{array}{l}10 \\
120 \\
10 \\
10 \\
10\end{array}$ & $\overrightarrow{7}$ & సี & 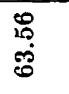 \\
\hline & ن் & $\begin{array}{l}50 \\
00 \\
10\end{array}$ & 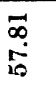 & $\begin{array}{l}8 \\
0 \\
\infty \\
0 \\
0\end{array}$ & 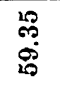 & $\stackrel{\leftarrow}{\oplus}$ & $\begin{array}{l}\sharp \\
\mathscr{8}\end{array}$ \\
\hline \multicolumn{2}{|c|}{ 营 } & 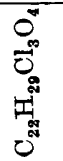 & 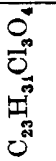 & 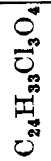 & 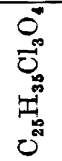 & 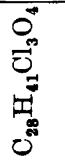 & $\begin{array}{l}0_{\infty}^{\infty} \\
D_{\infty}^{\infty} \\
T_{0}^{\infty} \\
0 \\
0\end{array}$ \\
\hline \multirow{2}{*}{ 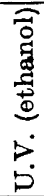 } & $\omega$ & $\begin{array}{l}8 \\
\infty \\
0 \\
0\end{array}$ & $\begin{array}{l}8 \\
\vdots \\
\vdots \\
0 \\
-1\end{array}$ & $\begin{array}{l}8 \\
\infty \\
0 \\
0\end{array}$ & $\begin{array}{l}8 \\
\stackrel{8}{6} \\
\approx\end{array}$ & $\begin{array}{l}8 \\
8 \\
5\end{array}$ & $\begin{array}{l}8 \\
8 \\
0\end{array}$ \\
\hline & 荷 & & స & 윰 & 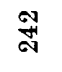 & & 욕 \\
\hline \multicolumn{2}{|c|}{ ن } & 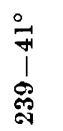 & 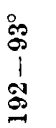 & 品 & $\begin{array}{c}\infty \\
\stackrel{\infty}{N} \\
1 \\
\stackrel{\leftarrow}{\sim}\end{array}$ & $\begin{array}{c}\circ \\
\infty \\
1 \\
1 \\
\infty\end{array}$ & $\begin{array}{l}8 \\
8 \\
1 \\
8 \\
8\end{array}$ \\
\hline \multicolumn{2}{|c|}{$\stackrel{7}{\oplus} 0^{\circ}$} & $\vec{\infty}$ & $\infty$ & 冓 & ชิ & $\overrightarrow{0}$ & $\stackrel{\mathfrak{N}}{\mathbf{N}}$ \\
\hline \multicolumn{2}{|c|}{ 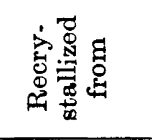 } & 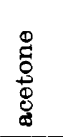 & 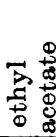 & 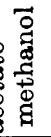 & 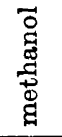 & $\begin{array}{l}\text { ¿० } \\
8 \\
8 \\
8\end{array}$ & 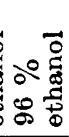 \\
\hline \multicolumn{2}{|c|}{ 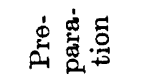 } & & - & $\rightarrow$ & $\rightarrow$ & N & N \\
\hline \multicolumn{2}{|c|}{$\sim_{1}$} & 田 & छే & 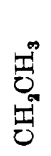 & 苞 & 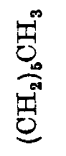 & 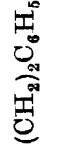 \\
\hline \multicolumn{2}{|c|}{ 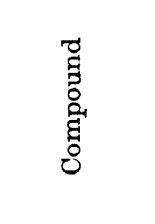 } & 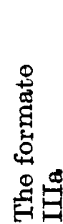 & 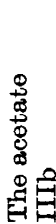 & 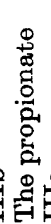 & 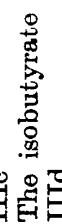 & 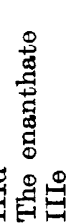 & 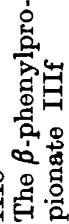 \\
\hline
\end{tabular}


mixture for a few minutes a clear solution was obtained, and after a few more minutes of shaking a solid precipitate was formed. The precipitate was collected on a filter, washed with benzene, and dried at room temp. in order to obtain the hemiacetal $(2.5 \mathrm{~g}), \mathrm{m} . \mathrm{p}$. $194-196^{\circ} \mathrm{C}$, raised by crystallization from ethyl acetate to $200-201^{\circ} \mathrm{C}$. U.V. $\lambda_{\max } 241$ $\mathrm{m} \mu$ in ethanol $\left(\varepsilon 16300\right.$ ). (Found: $\mathrm{C} 57.62 ; \mathrm{H}$ 6.70; Cl 24.61. Calc. for $\mathrm{C}_{21} \mathrm{H}_{29} \mathrm{Cl}_{3} \mathrm{O}_{3}: \mathrm{C} 57.87$; H 6.71; Cl 24.41).

The same properties are present if acetic acid is used as solvent. It is also possible to form II with chloral hydrate in chloroform in the presence of benzoyl peroxide.

Esters of the hemiacetal (IIIa, $b, c, d, e$, and $f)$.

1. With anhydride. II (3.0 g) was dissolved in a mixture of the anhydride $(10 \mathrm{ml})$ and pyridine $(10 \mathrm{ml})$. The solution was allowed to stand at room temp. for about $16 \mathrm{~h}$ and evaporated in vacuo. The residue was crystallized from ethyl acetate, acetone, or methanol to yield the ester.

2. With acyl chloride. To a chilled solution of II $(2.2 \mathrm{~g})$ in a mixture of dry benzene $(10 \mathrm{ml})$ and pyridine $(6 \mathrm{ml})$, a solution of the acyl chloride $(1.3 \mathrm{~g})$ in dry benzene $(5 \mathrm{ml})$ was slowly added while stirred. After standing for about $16 \mathrm{~h}$ at $+2^{\circ} \mathrm{C}$ ether $(150 \mathrm{ml})$ and ethyl acetate $(25 \mathrm{ml})$ were added, and the mixture was washed with $0.5 \mathrm{~N}_{2} \mathrm{SO}_{4}$, $0.5 \mathrm{~N} \mathrm{NaOH}$ and water. The solution was dried with sodium sulphate after which the solvent was removed in vacuo and the residue was crystallized from $96 \%$ ethanol in order to yield the ester.

The formate. Formic acid $(2.8 \mathrm{ml})$ was mixed with acetic anhydride $(7.5 \mathrm{ml})$, and the mixture was allowed to stand at room temp. for about $16 \mathrm{~h}$. This solution was added to a solution of II $(3.0 \mathrm{~g})$ in pyridine $(15 \mathrm{ml})$, and after standing for $5 \mathrm{~h}$ at room temp. the mixture was evaporated to dryness in vacuo. The solid residue was triturated with ether, filtered off and dried in order to yield the formate.

17-(1,2,2,2-Tetrachloroethoxy)-androst-4-ene-3-one (IV). To a chilled solution of II $(2.0 \mathrm{~g})$ in dry chloroform $(50 \mathrm{ml}) \mathrm{PCl}_{5}(1.0 \mathrm{~g})$ was added in small portions under continuous stirring. Having been stirred for about $1 \mathrm{~h}$ at $+2^{\circ} \mathrm{C}$ and for $1 \mathrm{~h}$ at room temp. the mixture was poured into a cold $\mathrm{NaOH}$-solution. The chloroform phase was separated from the aqueous phase, washed three times with water, and dried. The solvent was removed in vacuo, and the residue was crystallized from methanol to give the tetrachloro ether $(1.5 \mathrm{~g}), \mathrm{m} . \mathrm{p}$. $15 \mathrm{l}-155^{\circ} \mathrm{C}$, raised by recrystallization to $156-158^{\circ} \mathrm{C}$. U.V. $\lambda_{\max } 240 \mathrm{~m} \mu$ in ethanol $\left(\varepsilon=16800\right.$ ). (Found: 55.68; $\mathrm{H}$ 6.27; Cl 31.00. Calc. for $\mathrm{C}_{21} \mathrm{H}_{28} \mathrm{Cl}_{4} \mathrm{O}_{2}: \mathrm{C} 55.52$; H. 6.21; Cl 31.22).

17-(1,2,2-Trichloroethenoxy)-androst-4-ene-3-one (V). IV (2.3 g) in $15 \mathrm{ml}$ of a $5 \%$ solution of $\mathrm{KOH}$ in ethanol was refluxed for $20 \mathrm{~min}$. The mixture was then poured into water and the product was extracted with ether $(2 \times 100 \mathrm{ml})$. When the extract had been dried the ether was removed in vacuo and the residue was crystallized from methanol in order to yield the trichlorovinyl ether $(1.6 \mathrm{~g}), \mathrm{m} . \mathrm{p} .120-122^{\circ} \mathrm{C}$, raised by recrystallization to $128-130^{\circ} \mathrm{C}$. U.V. $\lambda_{\max } 240 \mathrm{~m} \mu$ in ethanol $(\varepsilon=19000)$. (Found: C 60.48; H 6.56; Cl 25.38. Calc. for $\mathrm{C}_{21} \mathrm{H}_{27} \mathrm{Cl}_{3} \mathrm{O}_{2}$ : C 60.37; $\mathrm{H} \mathrm{6.51;} \mathrm{Cl} \mathrm{25.46).}$

Acknowledgements. The author wishes to thank Mr. P. Mørch for ultraviolet and infrared spectra and Mr. G. Cornali for the micronalyses.

\section{REFERENCE}

1. Gaunt, R., Tuthill, C.H., Antonchak, N. and Leathem, J.H. Endocrinology 52 (1953) 420.

Received November 9, 1961.

Acta Chem. Scand. 16 (1962) No. 4 